\title{
NATO’s Energy Security Policy Put to the Caspian Test
}

\author{
Nathan R. Grison*
}

\section{Introduction}

As a bridge between the Middle East, the former Soviet republics, and the Euro-Atlantic zone, the Caspian Sea is increasingly at the center of the global geopolitical and commercial game. In addition to its strategic location, the Caspian Sea, according to analysts, could contain between 6 and 10 percent of the world's gas reserves, and from 2 to 6 percent of the world's oil reserves.

Defined in 1921 as an Irano-Soviet sea, the Caspian rapidly became a source of tension after the fall of the USSR. The increased number of littoral states, rising from two to five, made it necessary to redraw national sea borders and, maybe even more importantly, to redistribute the ownership of the resources lying under the Caspian seabed. As a regional agreement was never reached, each country has started granting permits for the extraction of hydrocarbons in what it considers to be its territorial waters. These conflicting claims recently led to a generalized and alarming military buildup across the region. As a result, in the past several years a number of armed incidents have been reported that have contributed to further destabilizing an already volatile region.

Moreover, this situation can have an impact on the energy security of NATO member states, and in particular those members of the European Union (EU), as they seek to diversify their sources of oil and gas supply. Their traditional hydrocarbon-exporting partners show signs of slowing down production, while consumption in the EU is expected to increase in the next decade. Some resource-rich countries could try to take advantage of this European dependency on their exports. In this regard, the 2006 gas crisis represented a wake-up call. With "fracking" developing rather slowly on this side of the Atlantic, Europe's dependency on Russian hydrocarbons should be balanced with new sources of supply. ${ }^{1}$ As expressed in the 2010 Common Strategy and 2012 Chicago Declaration, energy security is on the Alliance's agenda.

This article will argue that, although NATO has listed energy security as one of the main emerging security challenges the Alliance will face in the future, the example of the Caspian region highlights the difficulty for the Alliance in being active in the energy security domain, especially in a region where all the players are Partners or nonPartners and have their own security agenda. Moreover, translating the agreed language of the 2012 Strategic Concept into concrete actions is also difficult for the Alli-

Nathan R. Grison is Research Fellow at NATO Parliamentary Assembly. He holds Bachelor's degree in Political Science and Government and Master's degree in International Relations from the Institut d'Etudes politiques de Paris/ Sciences Po Paris.

1 Brad Plumer, "How Long Before Fracking Spreads to Europe? A Decade, at Least," The Washington Post (7 February 2013); available at http://www.washingtonpost.com/blogs/ wonkblog/wp/2013/02/07/will-fracking-ever-spread-to-europe-maybe-in-a-decade/. 
ance because the political will and the means of NATO member states necessary for the Alliance to become actively involved in this region are very limited. As a result, other international organizations, such as the EU and the Organization for Security and Cooperation in Europe (OSCE), have taken the lead in the area of energy security. The current militarization of the littoral states and the growing instability in the region, however, raise the question of the role NATO wants to play and where it could add value in the first place.

\section{The Caspian's Unsettled Legal Status}

Until the breakup of the Soviet Union, the Caspian Sea was exclusively and equally shared by Iran and the USSR as stated in treaties signed in 1921 and 1940 by the two countries. At the beginning of the 1970s, the Soviet Ministry for Oil and Gas Industry divided its share of the sea into four regional zones belonging to the littoral republics: Azerbaijan, Kazakhstan, Russia, and Turkmenistan. When the USSR disintegrated and these republics became independent, the geopolitical environment of the entire region was radically modified. The number of states owning a share of the Caspian littoral increased from two to five, with the three new littoral states not recognizing the previous treaties (to which they were not signatories). The main energy deposits being located outside the Russian share of the seabed, Moscow first backed the idea of creating a consortium to equally exploit and share Caspian resources. On their side, the three new independent states called for the sea to be divided into national zones. Russia changed its position as far as the seabed is concerned when it discovered new reserves off its shores in 1998. Iran insists that the Caspian be divided in equal shares among the five coastal states. The lack of a normative agreement on the legal status of the Caspian Sea, and thus on the division of territorial waters and hydrocarbon resources (as well as on the rules regulating the passage of pipelines along the seabed) presents significant obstacles to the exploitation of the many oil and gas fields that have been discovered beneath the Caspian's waters. This state of affairs has engendered several still-unresolved disputes.

Faced with the impossibility of signing a regional treaty, some littoral states have resorted to a series of bilateral or trilateral agreements. Kazakhstan signed a bilateral agreement with Turkmenistan in 1997 to partition the two countries' shares of the sea. Ashgabat has taken a back seat in the negotiations since then, and keeps its position intentionally unclear. In 2001 and 2003, Azerbaijan aligned itself with Russia and Kazakhstan, and the three countries agreed on the partitioning of the waters. Those agreements, nevertheless, do not specify the status of cross-border deposits (except those between Kazakhstan and Russia). Iran does not recognize the bilateral agreements that have been established between the other littoral states. The southern part of the Caspian basin - where most of the deposits have been discovered - is therefore the most disputed. Azerbaijan, Turkmenistan, and Iran all have zones of bilateral conflict in this region.

Finding a collective solution in order to definitively settle the legal framework of the sea becomes therefore more and more crucial. Three summits gathering the heads 
of the five littoral states have been organized, most recently in Baku in 2010. However, they all failed to resolve the question of the sea's legal status, or even to make any progress on the main issues discussed. ${ }^{2}$ The question at the core of the Caspian dispute resides with the very definition of this body of water: Is it a sea or a lake? On the one hand, Azerbaijan, Kazakhstan, and Turkmenistan insist that it is a sea, and national sectors should therefore be based on a median line. On the other hand, Iran defines it as a lake, and thus asserts that each state should receive a fifth of the whole body of water. Russia, for its part, has proposed that all five states share the waters - and thus the fishing rights - of the Caspian, which would render impossible the building of a pipeline across the sea. According to the Russian proposal, the seabed and the resources underneath would be divided along sectorial lines. Both cases imply substantially different outcomes for all littoral states. The definition of the Caspian directly impacts the delineation of maritime and seabed borders, and therefore the attribution of oil and gas fields to one state or another. Additionally, if the Caspian were defined as a sea, then there would be legal precedents obliging Russia to grant access permits to foreign vessels via the Volga River.

\section{Increasing Tensions}

In the absence of a stable legal framework, territorial disputes between littoral states are inevitable. Despite their unclear status, most of the deposits lying underneath the Caspian are currently being exploited, leading to dangerous military incidents involving Azerbaijan, Iran, and Turkmenistan. In 2000, an Azerbaijani vessel was denied access to oilfields in the southern Caspian by the Iranian Navy. ${ }^{3}$ Similarly, diplomatic cables obtained by Wikileaks and made public in 2011 revealed that Iran moved an oil rig into waters that are disputed between Azerbaijan and Iran in November 2009. Baku's inability to react to these incidents pushed Azerbaijan to continue increasing its military capacity and seeking greater military cooperation with external actors, the United States in particular. ${ }^{4}$

In June 2012, according to Turkmen border services, an Azerbaijani patrol ship took "unlawful actions" against a civilian ship carrying out what Ashgabat described as "scientific research" work in the Kapaz/Serdar oil field, a part of the Caspian disputed by the two countries. ${ }^{5}$ In 2008 , following a similar incident, the two states had reached an agreement that was supposed to halt all exploration in the area until the status of the

2 The only concrete achievement was a resolution adopted in 2008 that authorizes ships flying the flag of one of the five states to circulate in the Caspian.

3 “Azerbaijan's Military Exercises in the Caspian: Who Is the Target?" Eurasia Daily Monitor 9:94, Jamestown Foundation (17 May 2012); available at www.unhcr.org/refworld/ docid/4fbccbd92.html.

4 "Iran, Azerbaijan in Tense Caspian Standoff, Cables Show," Eurasia.net (4 October 2011); available at www.eurasianet.org/node/64268.

5 Keith Weber, "Azerbaijan and Turkmenistan Disputes and the Tragedy of the Commons," Rep's Blog, Center for Strategic and International Studies (15 November 2012); available at http://csis.org/blog/azerbaijan-turkmenistan-disputes-and-tragedy-commons. 
field was agreed upon. ${ }^{6}$ Furthermore, Russia has threatened through semi-official channels to take military action if Azerbaijan and Turkmenistan agree to the construction of a pipeline across the Caspian that would bypass Russian territory. ${ }^{7}$

Instead of fostering the creation of a collective agreement, the rising levels of competition and mistrust are pushing the region towards increasing militarization. These incidents, occurring in parallel to a general military build-up, may escalate into potential large-scale confrontations over the disputed oil and gas fields or the reluctance of some littoral states to agree to the construction of a trans-Caspian pipeline.

\section{Regional Military Escalation}

The legal black hole surrounding the delineation of the Caspian's national maritime borders has contributed to the emergence of tensions between the littoral states over the ownership of oil and gas fields. The Russia-Kazakhstan dispute has been managed diplomatically since $2002,{ }^{8}$ but the relationships between Azerbaijan and Turkmenistan, and Azerbaijan and Iran, remain extremely tense over Baku's signing of contracts with international companies for the exploration and exploitation of disputed oil fields.

As the five littoral countries are arguing over how to divide the basin among themselves, each capital seeks insurance that it can support its territorial pretentions with stronger military power. As a result, the Caspian basin has witnessed a militarization process that has considerably increased in the past years. In the 1990s, the majority of the five coastal countries tried to avoid the militarization of the Caspian Sea. With the fall of the USSR, Moscow proposed to share the former empire's military resources in equal parts among its newly independent republics, but only Azerbaijan accepted the offer. Turkmenistan and Kazakhstan refused, and favored a common fleet under Russian command. The latter was only short-lived, and the two states soon changed their positions as they confronted increasing national security challenges, and did not want to be dependent any longer on Moscow for their defense. In the last few years the postSoviet states have established their own military maritime infrastructure. Those naval build-ups will necessarily raise tensions, and increase the risk of conflicts breaking out in this volatile region.

Russia remains by far the uncontested leader among the Caspian naval powers. The Russian authorities defined the Caspian as a zone of national strategic interest at the beginning of the 2000s, and the Russian Navy's fleet has been steadily developed since then. In May 2011, the commander in chief of the Russian Navy announced that the

6 “Azerbaijan Angered by Turkmenistan's Work on Disputed Caspian Field,” Azernews (20 June 2012); available at www.azernews.az/oil_and_gas/42552.html.

7 Vladimir Socor, "Bluff in Substance, Brutal in Form: Moscow Warns Against Trans-Caspian Project," Eurasia Daily Monitor 8:217, Jamestown Foundation (30 November 2011); available at www.jamestown.org/single/?no_cache $=1 \&$ tx_ttnews\%5Btt_news\%5D=38723.

8 World Briefing "Europe: Russia, Kazakhstan: Caspian Pact," The New York Times (14 May 2002; available at http://www.nytimes.com/2002/05/14/world/world-briefing-europe-russiakazakhstan-caspian-pact.html. 
Caspian fleet would be allocated sixteen new ships by the end of $2020 .^{9}$ With its 148 vessels of multiple dimensions and functions, Russia already has the strongest presence in the Caspian Sea. Russia is strengthening its position in the Caspian to prevent it from falling under the influence of Western powers. Moreover, the Russian authorities have the capacity to create obstacles for other littoral countries that wish to increase their naval power, as it controls the only waterway into the Caspian: the Volga River. Moscow has so far allowed donated or purchased vessels to be shipped through that channel, but it may change its position on the issue at any moment. In order to be able to build its ships and remain independent, Azerbaijan has constructed its own shipyard. ${ }^{10}$ For their part, Kazakhstan has secured the help of South Korea to build its own in the near future, ${ }^{11}$ and Turkmenistan announced in January 2013 its plan to set up a ship repair and construction plant near the port of Turkmenbashi. ${ }^{12}$

Following the Russian example, Iran, which has the second-largest naval force in the region, has been strengthening its fleet. At the beginning of the 1990s, the Iranian Caspian fleet was obsolete, and Teheran had to engage in a large-scale modernization of its naval forces. Teheran announced in 2001 its intention to add another seventy-five missile ships to the fleet, already reportedly made up of sixty to ninety vessels. ${ }^{13}$ Teheran even stated in August 2012 that it will deploy light submarines in the Caspian Sea, ${ }^{14}$ and launched a new domestically built destroyer in March $2013 .{ }^{15}$ Iran's development of its military presence in the Caspian is causing worry in Russia, and is part of the larger general militarization of the basin. Despite the insistence of the two countries on their "strategic relationship," Moscow wants to ensure that it remains able to impose its will on the other littoral states, and therefore does not cast a favorable eye on the emergence of potential military competitors in the region.

Competition and mistrust led to the current situation. Intimidated by their neighbors' military superiority, which was only continuing to increase, Azerbaijan, Kazakhstan, and Turkmenistan felt compelled to react. The littoral countries see their counterparts' naval development as a security threat. Trying to keep up with two mightier military powers Russia and Iran, the three neighbors are now building their

9 "Russia to Strengthen its Caspian Sea Fleet," Russia Today (4 May 2011); available at http://rt.com/politics/caspian-fleet-missiles-warships/.

10 E. Ismayilov, "SOCAR: New Shipyard to Strengthen Azerbaijan's Position in Caspian," Trend.az (25 October 2011); available at http://pda.trend.az/en/1949224.html.

11 "Kazakhstan, South Korea to Mull Building a Shipyard in the Caspian Sea," Interfax.com (4 May 2012); available at www.interfax.com/newsinf.asp?id=329392.

12 "Turkmenistan to Set up Shipyard in Caspian Sea," Aernews.az (18 January 2013); available at www.azernews.az/region/48693.html.

13 Joby Warrick, "Iran Bolsters Retaliation Capability in the Persian Gulf, Experts Say," The Washington Post (26 July 2012); available at http://articles.washingtonpost.com/2012-0726/news/35488801_1_nuclear-facilities-gulf-region-persian-gulf.

14 "Iranian Submarines to Navigate Caspian Sea," Russia Today (30 June 2012); available at http://rt.com/news/submarines-caspian-iran-oil-123/.

15 "Iran Launches Destroyer in Caspian Sea," Radio Free Europe/Radio Liberty (17 March 2013); available at www.rferl.org/content/iran-navy-destroyer-caspian/24931091.html. 


\section{THE QUARTERLY JOURNAL}

own fleets from scratch. In this regard, the regional environment was modified when the United States declared the Caspian Sea vital to its strategic interests in the 2000s. In an attempt to strengthen its partners, Washington launched considerable military cooperation programs directed toward Kazakhstan, ${ }^{16}$ Turkmenistan, ${ }^{17}$ and above all Azerbaijan. $^{18}$

Azerbaijan is indeed becoming increasingly serious about its naval security. Until the demise of the USSR, the Soviet Caspian fleet was based in Baku. Azerbaijan kept the infrastructure left on its territory after it became independent, as well as a share of the Soviet ships. In recent years, the country has received thirty patrol cutters and three motorboats from the United States and Turkey. ${ }^{19}$ The U.S. also helped install maritime radar along the coast of Azerbaijan and establish a command-and-control center in Baku. More recently, Azerbaijan purchased anti-ship missiles from Israel. ${ }^{20}$ The U.S. Department of Defense has conducted several engagement exercises with the Azerbaijani Navy focused on building capacity for critical energy infrastructure protection. The main perceived threat in the Caspian for Azerbaijan remains Iran, but Russia could also become a source of trouble in the future if the negotiations between Azerbaijan and Turkmenistan over a trans-Caspian pipeline bypassing Russian territory were to lead to concrete results.

Following the same trend, Astana is boosting its maritime power. Kazakhstan possesses five ports on the Caspian, but none of them were used for military purposes during Soviet times. The Kazakh authorities have thus had to build a new naval infrastructure from scratch. After Kazakhstan withdrew from the Russia-led common naval protection arrangement in 1994, Nursultan Nazarbaiev affirmed in 2003 his intention to transform his country into a naval power by 2015. In April 2012 Kazakhstan

16 E. Kosolapova, "Kazakh and U.S. Defense Ministries Sign Cooperation Plan for 20132017," Azernews.az (11 December 2012); available at http://en.trend.az/regions/casia/ kazakhstan/2097637.html.

17 "For FY2013, [...] peace and security programs include Foreign Military Financing (FMF), for which the Administration has requested \$685,000; International Military Education and Training (IMET), for which the Administration has requested $\$ 350,000$; reforming law enforcement and combating drug-trafficking and trafficking in persons, for which the Administration has requested $\$ 550,000$; and combating weapons of mass destruction, for which the Administration has requested \$500,000." Jim Nichol, Turkmenistan: Recent Developments and U.S. Interests, CRS Report for Congress (Washington, D.C.: Congressional Research Service, 17 August 2012); available at www.fas.org/sgp/crs/row/97-1055.pdf.

18 Roger McDermott, "Azerbaijan Deepens Military Cooperation with the U.S. and NATO," Eurasia Daily Monitor 6:173 (22 September 2009); available at www.jamestown.org/ single/?no cache $=1 \&$ tx ttnews $\% 5 B$ tt news $\% 5 \mathrm{D}=35520$.

19 Marlène Laruelle and Sébastien Peyrouse, "The Militarization of the Caspian Sea: "Great Games' and 'Small Games' over the Caspian Fleets," China and Eurasia Forum Quarterly 7:2 (2009).

20 “Israel Signs \$1.6 Billion Arms Deal with Azerbaijan, Haaretz (26 February 2012); available at http://www.haaretz.com/news/diplomacy-defense/israel-signs-1-6-billion-arms-deal-withazerbaijan-1.414916. 
launched its first domestically produced missile boat, and it is planning to inaugurate two more ships in the coming months. ${ }^{21}$ There have also been talks about buying three more vessels from South Korea. ${ }^{22}$ Moreover, a new air base in Aqtau, a port city in the western part of Kazakhstan, opened in July 2011.

For its part, Turkmenistan has only had a minimal presence at sea for years. At the beginning of the 2000s, when its relations with Baku worsened, Ashgabat decided to commit to the naval protection of its Caspian interests by reinforcing its fleet. The country reportedly possesses only seven patrol boats, three guard ships with guided missiles (bought from Russia in 2008), two Sobol patrol boats, and two Molniya boats. However, despite Turkmenistan being officially neutral, the country's new naval doctrine states that "the naval forces are given the task of ensuring that the country's interests in the Caspian Sea are protected." ${ }^{23}$ With the help of Turkey and Ukraine, Ashgabat therefore established the country's first naval academy in $2011 .{ }^{24}$ That same year, Turkmenistan acquired two missile corvettes featuring new missile systems, placing those ships among the most heavily armed in the Caspian. In the latest episode of the militarization of the Caspian, Turkmenistan held in September 2012 its first ever naval exercise, officially directed against a nominally terrorist enemy, but the details of the exercise suggest that Ashgabat was drilling for a naval engagement with another country. This exercise recalls both Azerbaijan's May 2012 naval exercises and the Caspian component of the Collective Security Treaty Organization's 2011 exercise featuring Russian and Kazakh navies. In both cases, the scenario practiced involved an attack coming from the southern end of the sea, and carried out by exactly the same sort of aircraft that Iran owns.

In October 2005, the Russian Minister of Foreign Affairs Sergey Lavrov proposed the creation of a joint military force, CASFOR, to respond to transnational threats affecting the Caspian region. ${ }^{25}$ However, Kazakhstan, Turkmenistan, and Azerbaijan have politely turned down the offer until now, as they do not wish to engage in what would be an unequal partnership with Moscow.

As each littoral state is busily flexing its muscles, and no agreement is anywhere close to being reached on the status of the Caspian and the ownership of the resources lying beneath it, the risk of witnessing a further increase in tensions in the region lead-

21 D. Mukhtarov, "Kazakhstan Launches First Homemade Rocket Artillery Ship," Trend.az (25 April 2012); available at http://en.trend.az/regions/casia/kazakhstan/2018846.html.

22 Hossein Aryan, "Caspian Sea States on Course for Naval Arms Race," Radio Free Europe/Radio Liberty (27 July 2011); available at www.rferl.org/content/caspian_states on_course_for_naval_arms_race/24278751.html.

23 Catherine A. Fitzpatrick, "Turkmenistan Beefs up Caspian Presence, Irritating Russia," Eurasia.net (30 October 2011); available at www.eurasianet.org/node/64410.

24 “Turkmenistan Establishes Naval Institute under Ministry of Defense," Turkmenistan.ru (6 June 2010); available at www.turkmenistan.ru/?page_id=3\&lang_id=en\&elem_id= 17125\&type=event\&sort=date_desc.

25 Annie Jafalian, "Vers une militarisation de la mer Caspienne? Le projet de la CASFOR," Fondation pour la Recherche Stratégique (30 October 2005); available at www.frstrategie.org/barreFRS/publications/notes/20051030.pdf. 
ing to the breakout of an open bilateral or multilateral conflict remains high. The stakes are high in terms of energy security for some NATO members in the region, and those nations are therefore pressing the Alliance to contribute as much as possible to the stability of the Caspian. Though the 2010 Strategic Concept gives NATO a greater role in the area of energy security, their demands have not been translated into actions so far.

\section{NATO and the Caspian Region}

Since the 1990s, Western leaders and economists have seen the Caspian Sea as a part of the wider Eurasian energy corridor linking Europe to Central Asian energy supplies. The European Union wants to secure the transportation of Turkmen gas via Azerbaijan to Turkey and on to European consumers through a trans-Caspian pipeline, which could simultaneously help reduce Europe's energy dependency on Russia, foster stabilization of the Caucasian and Central Asian regions, and counterbalance Russia's influence in these areas. To achieve this goal, a settlement of the main disputes will have to be promoted, and confidence built among Caspian states.

European countries are not the only actors that have a keen interest in the legalization of the Caspian Sea's status. The Western companies that were granted contracts to exploit Caspian hydrocarbons wish to see the question of the Caspian's status resolved, since regional stability is essential to the security of their investments. On the other hand, Russia and Iran have an interest in delaying any agreement on the Caspian's legal framework, as they possess large reserves of hydrocarbon resources outside the sea itself and are not dependent on Caspian production. Iran wants to keep exerting influence across the region, and Russia refuses to see its territory bypassed by a pipeline linking Europe and Central Asia that would decrease European dependency on its supply of oil and gas. A the same time, cooperation with Iran, even simply at the level of political discussions, is rendered difficult by the lack of willingness on the side of Teheran, as well as the fact that the country is not a NATO partner and does not have any sort of official framework for discussion agreed on with the Alliance. Even though some members would want NATO's role in the region to be complementary to the EU's position, through the PfP program in particular, the Alliance has struggled to find an entry point to the geopolitics of the region.

NATO has been cooperating within the framework of the Partnership for Peace (PfP) with Azerbaijan, Kazakhstan, Turkmenistan, and Russia since the four Caspian littoral states joined the program in 1994. The purpose of the PfP is to increase stability and strengthen security relationships between NATO and its Partners, as well as among PfP countries themselves. The Alliance cooperates with Azerbaijan and Kazakhstan on defense-related work, defense reform, defense policy and planning, education and training, military-to-military cooperation and exercises, civil emergency planning and disaster-response, and science and environmental issues. The relationship with Turkmenistan has been more limited because of Ashgabat's official policy of neutrality. NATO and Russia mainly cooperate on the fight against terrorism and drug trafficking, and in the field of non-proliferation and arms control. Additionally, Azerbaijan currently contributes ninety-four soldiers to the ISAF mission. Kazakhstan and 
Turkmenistan have been central to the northern distribution network, which has been used to transport non-lethal supplies to ISAF forces in Afghanistan. Russia for its part has allowed NATO to use the airbase in Ulyanovsk as a transit point to relay non-lethal supplies. Even though NATO's activities in the region can help foster cooperative relations among its Partner countries, especially through confidence-building, the options are limited for NATO to play a role in the Caspian region and fully reach the goals the Alliance has set for itself in the 2010 Strategic Concept.

\section{NATO's Limited Options in Facing the Challenge of Energy Security}

Recently, energy security has emerged as an important topic on NATO's agenda. In its transition from a Cold War military alliance to an effective and proactive organization that is able to address emerging security challenges, NATO has increasingly recognized energy security as a growing concern. At the 2008 Bucharest Summit, heads of the NATO member states emphasized their readiness to see NATO contribute to energy security by advancing international and regional cooperation, protecting vital energy infrastructure, and engaging in information sharing. NATO's 2010 Strategic Concept renewed this commitment by emphasizing that NATO would "develop the capacity to contribute to energy security, including protection of critical energy infrastructure and transit areas and lines, cooperation with partners and consultations among Allies on the basis of strategic assessments and contingency planning." ${ }^{26}$ At the Chicago Summit, the leaders of the twenty-eight member nations repeated that "a stable and reliable energy supply, diversification of routes, suppliers, and energy resources, and the interconnectivity of energy networks, remain of critical importance." 27

Since the adoption of the 2010 Strategic Concept, NATO has been able to extend dialogue offers to its Partners in the domain of energy security. NATO indeed encourages dialogue with its Partners on issues of mutual concern in the energy security domain, in particular through the work of the Energy Security Section of its Emerging Security Challenges Division. In this regard, the PfP Program constitutes the best framework for cooperation with the Partners on energy security issues. The discussions that take place in this forum allow each PfP country and NATO itself to better understand the positions and concerns of all actors, and to advance international and regional cooperation in this field. Azerbaijan and Kazakhstan, for example, have hosted various events related to the topic of energy security, including the Euro-Atlantic Council Security Forum held in Astana in June 2009, which focused on Afghanistan and energy security. ${ }^{28}$

26 “Active Engagement, Modern Defence," NATO 2010 Strategic Concept, adopted at the Lisbon Summit; available at http://www.nato.int/nato_static/assets/pdf/pdf_publications/ 20120214_strategic-concept-2010-eng.pdf.

27 NATO Chicago Summit Declaration, 20 May 2012; available at www.nato.int/ cps/en/natolive/official_texts_87593.htm?mode=pressrelease.

28 NATO Press Release, "Security Forum Discusses Key Challenges in Central Asia," 25 June 2009; available at www.nato.int/cps/en/natolive/news_55920.htm?selectedLocale=en. 


\section{THE QUARTERLY JOURNAL}

Through the organization of international and regional workshops, events, and exercises, NATO helped create transnational professional networks. Through their participation in PfP events, Azerbaijani experts have been able to meet and build connections with experts from NATO Headquarters and Allied countries. After a first event organized in 2009, in November 2012 Baku hosted a seminar supported by NATO on the topic, "Ensuring energy security in the future and NATO's role in protection of critical energy infrastructure in the Caspian basin." By bringing together experts to share best practices and experiences, this international cooperative approach adopted by NATO's Energy Security Section indirectly fosters political stability. In the case of the Caspian Sea, in the long term the region is made more attractive to foreign investments, including from NATO countries, especially in the energy field.

In parallel, NATO staff also assists the Alliance's Partners in improving their preparedness and ability to recover, and tracks developments in the technological and environmental realms that can affect energy security. ${ }^{29}$ Moreover, NATO's Science for Peace and Security (SPS) Program organizes workshops that bring policy makers and experts together to discuss Euro-Atlantic energy security and supply.

The dialogue fostered by NATO on energy security issues with its Partners has been a success, as the example of the Caspian region shows. However, for two main reasons the wish to see NATO play a greater role in energy security issues expressed in the 2010 Strategic Concept has not been fulfilled.

The first reason lies in the lack of consensus among the Allies on NATO's role. Even though NATO's European members were collectively affected by the January 2006 Ukraine-Russia gas dispute, the Allies have often adopted individual national policies with regard to threats to energy security. While some countries within the Alliance are pushing for a strong commitment on this issue, others are indeed more reluctant to accept a leading role for NATO. Poland, the Baltic States, and Romania in particular are calling for NATO to play a more prominent role in Europe's energy security.

The second reason is the difficulty of engaging unwilling states. In the Caspian region, NATO has to deal with both Russia and Iran. Dialogue with the latter was nonexistent over the past thirty years until mid-March 2009, when informal talks were held between the two parties. NATO negotiator Martin Erdmann met with the Iranian Ambassador to the European Union, Ali-Asghar Khaji. ${ }^{30}$ For its part, Russia has never taken a favorable view of NATO's involvement-however limited - in the Caspian region. Moscow wants to remain at the center of the Caspian energy game. The Russian leadership seems keen on keeping the Central Asian and Caucasian countries dependent on its network of pipelines, maintaining European dependence on its energy ex-

29 For more information on NATO's approach to emerging security challenges, see Ioanna-Nikoletta Zyga, "Emerging Security Challenges: A Glue for NATO and Partners?" NATO Defense College, Research Paper No. 85 (30 November 2012); available at www.ndc.nato.int/ news/current_news.php?icode $=470$.

30 "Iran and NATO End 30-year Impasse," BBC News (27 March 2009); available at http://news.bbc.co.uk/2/hi/middle_east/7966263.stm. 
ports as a result. Russia looks disapprovingly at the creation of new energy infrastructure projects, and therefore opposes the construction of a trans-Caspian gas pipeline from Turkmenistan to Azerbaijan, ${ }^{31}$ as well as an oil pipeline from Kazakhstan to Azerbaijan, which would be linked with the Baku-Tbilisi-Ceyhan pipeline, bringing Caspian hydrocarbons to the Mediterranean. If built, those pipelines would have a noticeable impact on the hydrocarbon supply networks of the Euro-Atlantic area. They would allow for lower prices in the gas market, a reduced European energy dependency on Russia, and a decrease in Russian influence on the Caspian littoral regions.

In order to dispel misperceptions on the role it aims to play in the area, NATO has reduced its role in the Caspian region to a minimum, and has tried to focus its dialogue efforts on the management of common transnational threats affecting both Russia and NATO. Despite the existence of the NATO-Russia Council (NRC) since 2002, up until now energy-related questions have been rarely, if ever, discussed in the NRC. Russia prefers to address those concerns outside of the multilateral framework, often on a bilateral basis, and prefers to focus instead on hard security issues in its discussions with the Alliance.

\section{Recommendations}

The 2010 NATO Strategic Concept outlines the need for an increased engagement of NATO in dealing with energy security threats, and insists on the inclusion of Partners in addressing this issue. However, the example of the Caspian region shows how difficult the implementation of these principles has been for the Alliance. Despite the emphasis placed in recent years within NATO on addressing emerging security challenges, including energy security, the translation of those words into concrete action has been rather limited so far. Apart from having extended useful (but limited) dialogue offers, NATO has not expanded its role in the field of energy security.

The Caspian region has been studied in this essay as a test case of the limitations faced by the Alliance in the implementation of its energy security policy. The following recommendations could help to define more clearly where NATO could add value:

1. NATO could outline more precisely what role it wishes to play in the Caspian region. Political dialogue should be at the core of NATO's relationship with the Caspian littoral countries. The Alliance's efforts in coordinating with its Partners have to be continued and pushed farther. NATO should function as a forum for regional cooperation by engaging more often and more in-depth with its Partners in the region. Taking into account the absence of any formal multilateral framework for dialogue in the Caspian region, NATO should support its Partners in finding opportunities to discuss issues of common in-

31 After years of political hesitations on the part of Ashgabat, the European Union (EU) was finally able to engage in September 2011 in negotiations with both Azerbaijan and Turkmenistan on the construction of a trans-Caspian natural-gas pipeline. See European Commission Press Release, "EU Starts Negotiations on Caspian Pipeline to Bring Gas to Europe," 12 September 2011; available at http://europa.eu/rapid/press-release_IP-11-1023_en.htm. 
terest. With the PfP countries concerned-Azerbaijan, Kazakhstan, Russia, and Turkmenistan-NATO should hold more frequently $28+1$ and $28+\mathrm{N}$ meetings, at the ambassadorial level or below.

2. NATO should make cooperation with its Partners on energy security a clear priority area for dialogue, discussion, and coordination in its Individual Partnership Programs (IPAPs). Furthermore, in coordination with their Partners, Allies should define and list the means and mechanisms they need to meet the challenges of energy security in the Caspian region and in other geographic areas.

3. In parallel, specific efforts should be made to improve NATO's relationship with Russia. Political dialogue and discussions on regional stability have to be at the center of the partnership with Russia. Taking steps towards confidence building between Moscow and Brussels will be essential if NATO intends to avoid unnecessary tensions and diffuse misunderstandings about its intentions. The recent appointment of a new Russian Ambassador to NATO is to be seen in this context as a positive sign, as it will allow for discussions at the North Atlantic Council in the framework of the NRC to resume after a year of inertia.

4. Partners in the region, such as Azerbaijan and Kazakhstan — and, to a lesser extent, Turkmenistan - welcome NATO's support for the reform of their defense institutions. The Alliance should therefore contribute further to the professionalization and standardization of the Caspian littoral states' military forces and structures. Setting up shared standards can indeed help build confidence among the concerned Partners and avoid misunderstandings.

5. As part of its outreach strategy, NATO and its Emerging Security Challenges Division could increase the number of conferences it holds related to energy security. It could also create new courses addressing the issue and open them to nationals of Partner countries. Additionally, NATO should invest significantly in best-practices exchanges and emergency preparedness trainings regarding the protection of energy infrastructure.

6. NATO will have to recognize that it needs to engage countries, such as Iran, which view the Alliance as a negative factor in their own security equation. As the example of the Caspian region has shown, NATO's outreach and preventive work can only be effective if the Alliance listens to and takes into account the point of view of these actors.

7. NATO should cooperate more closely with the OSCE and the EU in both formal and informal formats on energy security. In order to avoid duplication in their regional programs, international organizations should design a common working plan, clearly defining the role of each organization in this domain. 


\section{Bibliography}

Laruelle, Marlène, and Sébastien Peyrouse. "The Militarization of the Caspian Sea: 'Great Games' and 'Small Games' over the Caspian Fleets." China and Eurasia Forum Quarterly 7, no. 2 (2009).

McDermott, Roger. "Azerbaijan Deepens Military Cooperation with the U.S. and NATO." Eurasia Daily Monitor 6, no. 173 (2009).

Socor, Vladimir. Bluff in Substance, Brutal in Form: Moscow Warns Against TransCaspian Project In Eurasia Daily Monitor, Jamestown Foundation. Vol. 8., 2011.

Zyga, Ioanna-Nikoletta. Emerging Security Challenges: A Glue for NATO and Partners? NATO Defense College, 2012. 